\title{
What does it take for flexible learning to survive? A UK case study
}

\begin{abstract}
Purpose: To identify potential reasons why an innovative Work based learning shell framework has succeeded in an adverse environment

Design/methodology/approach: Case study

Findings: Demand-led, flexible Work based learning programmes have to overcome a number of internal cultural and institutional barriers in order to succeed. Important requirements are likely to include effective leadership, financial viability, adherence to Quality Assurance, adaptability, entrepreneurialism and a cohesive community of practice incorporating these traits.

Research limitations/implications: The conclusions are drawn from shared experience and are suggestive only as they are not readily susceptible to empirical verification. The authors accept that for some the conclusions appear speculative but they suggest that in order for innovative programmes to survive more is required than sound pedagogy.

Practical implications: Although lessons may not be directly transferable, the paper draws attention to the importance of managerial, leadership and organisational factors necessary for innovative Work based learning programmes to survive and develop.
\end{abstract}

Social implications:

Originality/value: There is some literature on why some innovative higher education programmes and institutions have failed: there is little on why some programmes are successful. 


\section{Introduction}

There is a well established narrative that higher education must in future be more closely aligned to the requirements of a rapidly changing labour market. The keys to such provision are thought to be personalised, flexible lifelong learning relevant to the workplace rather than the traditional focus on subject discipline (Ehlers and Kellerman 2019; Redecker and Punie 2013). There have been within the UK and elsewhere many Work based learning programmes which accord with this prescription but they have had to struggle with both internal and external pressures. The latter have been especially acute in the UK. Between 2010-11 and 2015-16, the numbers on part-time Bachelor level programmes in England have decreased by 51 percent (Universities UK 2017: 22). The greatest falls have been since 2012, following the introduction of full cost tuition fees in England and the withdrawal of living support grants (Tucket 2017; Callender and Thompson 2018). The decline in numbers has been accompanied by the disappearance of virtually every state initiative designed to facilitate lifelong higher education. At a recent conference to mark the twentieth anniversary of a UK government paper, 'The Learning Age' (Department for Education and Employment 1998) which was supposed to herald a new era in part time adult provision, the keynote speaker had instead to list how each initiative had in turn been ended (Field 2018). Failed initiatives include the University for Industry, the e-University and Individual Learning Accounts (Lester 2015; National Audit Office 2002). The decline is mirrored in the closure or diminution of a number of 'flagship' Work Based Learning (WBL) programmes, notably former leading providers at the University of Derby and Middlesex University. Nixon et al. (2006) provided the first the first snapshot of WBL practice in the UK and of the seven cited case studies of WBL centres all but two have disappeared or been broken up. Outside the UK, Gustavs and Clegg (2005) report the closure of a similar WBL programme in Australia. 
In the same year (1998) The Learning Age was published the Work Based and Integrative Studies (WBIS) programme, similar in many ways to the Work Based Learning and Learning Through Work frameworks at Middlesex and Derby respectively, was created at the University of Chester. From a start with just six students it has grown steadily and today has over a thousand and shows every sign of continuing to flourish. Given the similarities with other WBL frameworks, the reasons for its apparent success would indicate reasons other than pedagogy have been responsible. This paper attempts to explore some possible reasons why. This is not to suggest there are easily transferable lessons; the high rate of attrition suggests there are more fundamental factors inhibiting the development of programmes aligned with the needs of lifelong learners in the current age.

\section{WBIS programme design}

WBIS is an example of a shell framework ${ }^{1}$ where students are able to negotiate their own award and curriculum (Talbot 2017; Wall 2010). The key organising principle for conventional programmes is instruction in a subject. In WBIS no subject is assumed but the framework enables learners to create knowledge relevant to their professional practice within it. Whatever is studied must be relevant to the work of the student and for its part the university must be able to provide underpinning knowledge and expertise in order to facilitate the development of practice knowledge. The framework can be used for individuals or cohorts, for short awards such as Post Graduate Certificates (30 Level 7 ECTS credits) or full, named awards such as Bachelor and Masters degrees. It can incorporate the past learning of students as well facilitate current and future oriented learning. Unlike conventional programmes, it does not seek to inculcate universal knowledge but aims to create relevant practice knowledge for application within a formally structured and accredited academic framework. There are few formal 
attendance requirements. Students can study where and when it is convenient for them to do so. They can register at any time and study at their own pace. For some, like Barnett (2014) the term 'flexibility' in learning has little meaning; we disagree. WBIS is designed to be as flexible as possible so that those with busy lives can access higher education relevant to their needs and circumstances.

To understand how it works in practice we will assume the example of a single learner. Upon enrolment most WBIS students complete a 'Self Review' module where they review past learning, identify their current professional role and provide a rationale for their future professional development as the basis for creating a 'pathway' (ie curriculum) with WBIS. This and the award title is a matter of negotiation between the learner and university. They will also complete an exercise in structured reflective learning in which they submit personal professional experience to analysis, using authoritative literature to inform their thinking. 'Authoritative' literature in WBL can be academic or from other, practice relevant sources (Costley and Nottingham 2018). An important aspect of the programme is to sensitise learners so they become conscious of learning from experience, as the basis for all future professional development. Students are therefore prepared not just to complete the programme but become active lifelong learners. Each learning pathway within WBIS reflects the requirements of the individual and must be progressive and coherent in the same way any other curriculum is created. It may include claims for past learning and current experiential learning, usually in the form of workplace projects as well as traditional subject discipline modules. WBIS students can take any module accredited by the university provided it is relevant and at the appropriate level. There is also a suite of modules created by WBIS tutors over time covering topics for which there is proven demand. These include generic topics such as Programme and Project Management, Financial Management, Management and Leadership and so on. The University 
has a dedicated panel to accredit new modules on a rolling basis as required. Delivery is via a variety of mechanisms including workshops, e-learning and individual tuition. In assignments students are encouraged to base their learning around real workplace issues, read relevant literature and consider how practice can change. Formative assessment is used to assist with personal development.

During the early years of the WBIS framework, most students proceeded through the programme in this way as individual learners. In recent years, the framework has been increasingly used to deliver to cohorts by other organisations, negotiating pathways on behalf of individuals in what is known as 'co-delivery' arrangements (Talbot, Perrin and Meakin 2014). Contrary to the pessimism of Reeve and Gallagher (2005) who see such as arrangements as inhibiting the development of WBL, co-delivery has enabled WBIS to grow and maintain financial viability. The trans-disciplinary nature of the framework lends itself to the creation of highly niche programmes. Examples include small animal surgery for veterinary surgeons, the assessment of drivers with impairments, hoteliers in Denmark, housing professionals and people working in Wall Street and the City of London. The most recent use of WBIS has been for Degree Apprenticeship programmes. The Chartered Manager Degree Apprenticeship (WBIS) programme began in 2016, with a postgraduate Senior Leader's Degree Apprenticeship (WBIS) in 2018 (Rowe, Perrin and Wall 2017).

\section{The origins of WBIS}

There are various strands in the story of how WBIS came to be created and a broader context which has enabled it to develop. The broad context is the economic, social and psychological changes of the last thirty years. Giddens (1991) has charted how changed economic structures has meant personal identity has ceased to be our occupation and become instead an individual narrative, underpinning what Beck and Beck-Gernshein (2002) have called 'institutionalised 
individualism'. WBIS, with its individual approach to learning, is at one level a product of our times but it did not create itself. There is a story of the development of WBIS as a product of developments in theories of learning and knowledge. There is also a wider story about these theoretical developments were picked up elsewhere and transferred to Chester. Finally there is the concrete narrative, about who did what and when within the University. We will deal with each in turn.

The theory which underpins its design and practice is largely within the constructivist tradition from Dewey (1916) onwards. From Knowles (Knowles, Holton and Swinton 1980) and Brookfield (1985) comes the idea that the learning requirements of adults are distinctive and best facilitated by means of self-direction. Also from Knowles is the idea of a negotiated learning contract rather than a prescribed curriculum. From Lewin (1951) and Rogers and Freiberg (1994) there is the belief in the value of experiential learning and from Deming Edwards (1994) the practice of informed analysis of experience by reference to authoritative literature. The mechanisms by which active learning from experience occurs has been developed by Kolb (1984) and many others. There have also been significant developments in our understanding of learning in the workplace. From Lave and Wenger (1991) the insight that workplace learning is cumulative, social and deeply contextualised. The Dreyfus and Dreyfus (1980) model of skill acquisition provides a conceptual framework for monitoring the progress of learning while its adaptation by Eraut (1994) enables better understanding of the gradual achievement of professional competence. Others, such as Marsick and Watkins (1990) have identified the way that much workplace learning is informal, incremental and incidental whilst Billett (2001) has identified more formal, structured workplace learning mechanisms. All of these elements are synthesised into WBIS pedagogic practice. 
Alongside developments in understanding of learning has occurred a broader conception of knowledge which also informs practice. WBIS recognises the distributed nature of knowledge rather than assuming the academy is its sole guardian and arbiter. The acceptance of the idea of 'tacit knowledge' (Polanyi 1983) has enabled both a better understanding of practice knowledge (Smith 2001) and the acceptance of 'trans-disciplinarity' - the recognition that knowledge exists not only within and between subject disciplines but also external to them (Nicolescu 2002; Costley and Pizzolato 2017). There has also been advances in our understanding of the development and sharing of knowledge within organisations outside the academy (Nonaka and Takeuchi 1995) and a distinction drawn between the kind of universal knowledge created in academia (Mode 1) and that for application in specific contexts- Mode 2 (Gibbons et. al. 1994). The revival of interest in application has led to a re-engagement with Aristotlean conceptions of phronesis (Flyvbjerg 2001) and praxis (Carr and Kemmis 1986). All of these theoretical advances are integrated into what might be called Raelin's (1999) and Boud and Solomon's (2001) manifestos for Work based learning- and are embedded in the design of WBIS.

The external story of WBIS-type practices begins with the Independent Study Programme (ISP) at the former North London Polytechnic, which ran from 1974 to 1989 (O'Rielly 1989). ISP used learning contracts to enable students to create their own curriculum from any module in the institution. Students began with a review of past learning, very much as happens on WBIS today. Another early user of whole programme learning by contract was the BA (Hons) Applied Social Studies (By Individual study) created by Manchester Metropolitan University 1981-1991 (Piper and Wilson 1989). These early forerunners anticipated the first work based, transdisciplinary shell framework developed at Middlesex University, another North London institution in 1995 (Portwood and Garnett 2000; Lester and Costley 2010). 
The internal narrative begins during the 1980s when some full time students at Chester were offered unaccredited work placements. The placements were partly a response to student demands for greater 'relevance' but also reflected an interest among tutors in the idea of experiential and reflective learning. There has also been a steady flow of policy documents from government and industry urging formal education to become more relevant to the labour market and industry (Sutherland 1998; Department for Education and Skills 2003; Lambert 2003; Leitch 2006). None of these have had a direct impact but they have created a climate more conducive to the creation of Work based learning. The one specific impact of the state was funding by the Manpower Services Commission of the Learning from Experience Trust ${ }^{2}$ in the early 1990s, which facilitated the process of translating experiential learning into academic credit (Evans 2000). This proved the key to the greater expansion of placement learning for full time undergraduates so that today almost all second year students at Chester complete a placement or undertake experiential learning as part of their degree. The accreditation of work placements for full time students in turn led to much greater contact with employers, some of whom asked if it was possible to develop accredited learning for their employees. The WBIS framework was created in response to this demand and validated in 1998. WBIS is broadly similar to the Middlesex Framework although there are variations in practice. From the outset WBIS has sought to integrate generic subject discipline modules alongside experiential learning rather more than has been the case at Middlesex. There is therefore greater emphasis on WBIS tutors creating and delivering content, more recently using online learning, than has been the case at Middlesex. Although it is possible to claim two thirds of an award for past learning in both, Chester students usually make smaller claims. Another difference is that while both allow for short awards, these have been more prevalent at Chester. 


\section{WBIS as academic practice}

Just as theoretical developments have influenced the overall design of WBIS so developments in pedagogical practices have had an impact. The introduction of credit systems and learning outcomes in the 1980s (now part of the European Qualification Framework) has created the architecture for a programme like WBIS as it enables the quantification of learning and thus makes the process of translating it into formal credit transparent (UDACE 1992). The reliance of traditional approaches on didactic instruction in lectures is rejected as ineffective (Bligh 2000) Instead learning is assumed to occur when the learner constructs their own meanings during the assessment process (Wiggins 1998). The use of learning contracts is based upon Knowles's (1986) pioneering work. The use of formal literature to inform experiential learning is derived from the ideas of Deming Edwards (1994). The utilisation of formative assessment as routine practice is derived from Bloom, Hasting and Madaus (1971). Feedback relies upon the notion of 'scaffolding' so that the learner is not counselled for perfection but is encouraged to develop to the next step in their development (Wertsch 1985; Vygotsky 1978). Feedback itself is structured so that learners are given clear directions on how to improve (Kluger and DeNisi 1996)

Given the variety of WBIS students there is a corresponding variety in delivery methods. All WBIS students have a Personal Academic Tutor who guides them through the process, as well as facilitate generic WBIS modules such as the aforementioned Self Review, claims for past learning and current experiential learning based around workplace projects. Learning for subject specific modules is facilitated by specialists from within the university and outside. The pattern of delivery is complex, involving personal tuition, workshops and e-learning. Students can bring in professional or MOOC learning (non-formal learning), past experiential learning (informal learning) as well as past certificated learning (formal learning). The role of a WBIS tutor is more complex than on a conventional programme. Each tutor must have a working knowledge of 
credit systems, learning outcomes and learning levels within the context of the European

Qualification Framework. Each must be familiar with the process of curriculum design and the accreditation of past learning. All tutors have particular areas of specialist knowledge but they must also be prepared to learn along with the student as the 'guide on the side' rather than the sage on the stage (King 1993). This requires an ability to navigate a body of literature (which will include professional and other material as well as academic sources) and identify not only what is not only relevant but authoritative. Beyond the more formal academic requirements associated with WBIS pedagogic practice, tutors must also have marketing and other organisational skills. We will address the importance of these additional skills in the following section when considering how the programme has managed to prosper.

\section{How has WBIS succeeded?}

We have previously noted that the reasons for success and failure of WBL shell frameworks is, given their similarities, unlikely to be for pedagogic reasons. We are aware that institutional resistance also plays a role but there are other factors likely to be at play. It is impossible to comment upon the specific circumstances within each institution but we can attempt to identify factors we believe have made WBIS successful. The list is not intended to be prescriptive or mutually exclusive. Nor is it implied they are lacking elsewhere. But collectively they seem to us important underpinnings for the longevity of WBIS and may help others seeking to establish and maintain similar frameworks.

\section{Effective leadership}

It is difficult for someone not involved in a programme like WBIS to understand how difficult it is to establish its legitimacy within the wider university and then deal with the myriad of practical problems associated with something run along completely different lines to everything else in the organisation. Many of the difficulties in the early years of the programme resulted from a 
questioning of its academic legitimacy. Collini (2012) expresses the view held by many in higher education- that university study is an end in itself and vocational education is 'training' with no place in the academy. Basit et al (2015: 1007) at Staffordshire University has affirmed that many of their colleagues think of Work based learning as 'training' and therefore not 'education'. WBL is a fundamentally different enterprise to traditional higher education and is perceived by many as running counter to institutional mission, requiring significant leadership (Garnett 2007).

Although we are using the term 'effective leadership' there is little agreement in the literature as to what that means, save it is like beauty- you know it when you see it (Bennis and Goldsmith 2010). In the context of higher education, Prysor and Henley (2018) have characterised leadership as 'Boundary spanning' (requiring a complex skill set) but the leadership they describe is not one which challenges the culture of the institution itself. It is hard to avoid the conclusion that WBIS has in large part succeeded because of the quality of leadership- both strategic and operational. During the twenty year lifetime of WBIS there has been consistent support for the programme from an unusually long serving Vice Chancellor. Strategic leadership in this sense has been facilitative but it has not been unconditional. An important part of operational leadership has been to remain cognisant of the broader aims of the university. Especially important in this respect is the ability to find and retain students whilst maintaining academic standards. A second important task has been managing the interface with the rest of the university. A programme as flexible as WBIS does not fit very well with existing administrative arrangements. Students are admitted at any time of year, they progress at their own pace, the number of enrolments on particular pathways is variable, there are different requirements for the library, progression is less predictable and so on. Culturally universities are in Burns and Stalker's (1961) term 'mechanistic', whereas WBIS requires a more adaptive 'organic' approach. Many of the university's administrative processes and procedures do not 
work well for WBIS. Even minor changes to the regulations, which suit the rest of the university or the way data is stored and collected are often problematic from a WBIS perspective. To lead CWRS requires a forensic attention to detail, an ability to represent its interests in the wider organisation and an acute sense of internal politics. Within the WBIS team it also requires the skills of 'near leadership'- a facilitative and inclusive approach (Alimo-Metcalfe and AlbanMetcalfe 2005).

\section{Financial viability}

The internal funding arrangements of universities are notoriously opaque but it is widely accepted that most general purpose, public universities are run on type of portfolio theory basis so that some departments subsidise others (Shattock 2010). Departments like Business and Law are expected to make money while others, say Philosophy might be allowed to run at a loss for reasons of contribution to scholarship, status and history. Work based learning does not provide much social capital for the university so it is apt to be seen principally as a source of income. Leading WBIS requires an acute awareness of financial returns so that every attempt is made to ensure they exceed the sector average of $40-45$ percent (Hillman et. al. 2018).

A second measure of efficiency is the Staff-Student Ratio (SSRs) - the number of full time academic staff to full time equivalent students. The OECD gives an average figure of 1:16 in all UK tertiary institutions (OECD 2017: 360) - the OECD average. Within the sector 1:25 is considered efficient but for WBIS, the ratios are often higher. Although we have used the example of an individual learner on WBIS to explain the pedagogical method, individually negotiated learning is uneconomic. Individual tuition survives because the programme overall is viable as well as playing a role in marketing. Individual learners who have a positive experience sometimes bring in their organisation. Overall viability results from the co-delivery arrangements referred to above. In co-delivery, partner organisation programmes are 
translated into accredited university modules and qualifications. The co-delivery organisation then delivers to cohorts and undertakes assessment. A WBIS link tutor undertakes second marking and is responsible for quality assurance, in return for a fee.

Maintaining overall viability requires finding a steady stream of new clients. In universities with WBL centres, there is often pressure from management to create large cohorts from a limited number of clients in order to achieve economies of scale. While this logic works well for traditional subject bound cohorts it is different in WBL. Employers often do not send students in predictable numbers nor is it possible to know in advance which employer(s) will deliver the greatest numbers. One of the reasons for the failure of some WBL departments is an overreliance on one or two sources of income. Like single industry towns, when the company pulls out the whole town is in trouble. Maintaining viability over a long period of time requires a diverse range of clients just as in any portfolio (Amenc and Le Sourd 2003). Regular reviews of performance removes clients who underperform by failing to bring many students, offset by the more or less constant influx of new partners. Although there are procedures designed to identify viable co-delivery partners, it is impossible to know for certain in advance who will deliver. The review of co-delivery partnerships ensures the overall operation remains profitable.

\section{Quality Assurance}

In addition to making money and working efficiently it is essential a non-standard programme like WBIS maintains academic standards. WBL is not an academically prestigious activity and in the minds of some it is associated with low academic standards (Anonymous 2002). While maintenance of standards is relatively straightforward when WBIS tutors deliver directly to students, the same may not be true when other organisations deliver and assess as happens in co-delivery arrangements. The perils of failing to adequately quality assure when working with partner organisations is well illustrated by the example of the University of Wales in 2011. A lack 
of oversight of institutions delivering their programmes resulted in the virtual destruction of the institution within a matter of months (Davies 2011). From the university's perspective WBIS represents the potential for considerable reputation damage.

The solution is for a commitment to quality in the WBIS tutor team and those parts of the university concerned with process and oversight. Having a 'quality culture' is more than having effective compliance mechanisms. It has to be embedded in everyday tutor practice (Talbot, Perrin and Meakin 2014 ibid.). Despite this, it is not surprising that the university has been nervous in respect of Quality Assurance. To some extent these fears have been allayed by a very favourable review by the Quality Assurance Agency during its last institutional review. It was included as an example of 'good practice' (Quality Assurance Agency 2010).

\section{Adaptability and entrepreneurialism}

As WBIS is a programme tailored to the requirements of adults in work it sits completely outside the university's normal marketing and promotional activities which are largely geared towards the recruitment of school leavers. Marketing the programme has therefore been the responsibility principally of WBIS staff themselves. Few if any students appear because they have seen the programme listed in the university Prospectus. Some individuals and organisations come through word of mouth recommendations. Others find the programme online or through platforms such as LinkedIn. WBIS tutors undertake some promotional activity by attending marketing events, searching tender lists and exploiting new funding streams. The UK government's Apprenticeship levy is a good example of the latter. Since 2017 the UK government has imposed a compulsory levy on companies which can redeemed to pay for apprenticeships with accredited institutions (Powell 2017). Using WBIS, one of the UK's first degree Apprenticeships was created in 2016, in anticipation of significant state funding from 2017 (Rowe, Perrin and Wall ibid). 
WBIS tutors constantly seek new students to replace learners and partner organisations exiting. There also has to be adaptation to changed external circumstances. The prolonged squeeze on public sector spending since the crash in 2008 has led to a re-balancing of the portfolio of clients and students. Figures are not kept on the ratio between public and private sector employed students but there has been a major shift away from public to private sector based students. The second major external event to affect demand was the introduction (in England) of full cost tuition fees for undergraduates in 2012. Postgraduate tuition fees have to date remained unchanged and are therefore lower so that since 2012 there has been a shift from undergraduate to postgraduate tuition. In addition to adapting to external market pressures there have also been major changes in the mode of delivery. Whereas in the early days of WBIS all students were local, now the majority are distance learners so that e-learning platforms have had to be developed. These have evolved so that whereas initially tutors spent a lot of time creating original content, online modules now are created using existing material wherever possible. It is standard policy to order all textbooks as e-books. These, alongside online journals and multi-media materials are integrated into learning platforms. In addition a specialist YouTube channel has been created for students. Further developments in practice include greater support for those with learning difficulties, the introduction of a Professional Doctorate and the creation of a culture increasingly given to research and scholarship. A recent five year review of the programme revealed a doubling of research outputs between 2012-2018.

\section{Cohesive community of practice}

WBIS is an example of a bottom up initiative so that it has always been 'owned' by those who deliver it. Successful development of the programme has required the recruitment of appropriate staff. In the past this proved difficult since contracts were usually temporary and experience with WBL elsewhere extremely limited. The delivery of WBIS requires a high degree 
of teamwork involving cooperation between academic and operational staff. Positive team behaviours, such as high levels of commitment to team goals, mutually supportive actions and mutual inter-dependence are all evident in the WBIS team (Aube and Rouseau 2005). Underpinning actions is a set of shared values and professional ideology. Values include a commitment to the learner over all other stakeholders, a belief in the worth of vocational learning and widening social access to university learning. 'Learning' and associated topics are part of everyday discourse. The routine use of formative assessment is underpinned by a faith in the ability of students to progressively develop cognitively under guidance. Students are encouraged to produce practical outcomes from their assignments wherever possible. The belief in learner-centredness sees no contradiction between a commercial approach and the requirements of formal academia. While some might regard WBIS as the essence of co-opted 'neo-liberalism', for those associated with the programme it is simply trying to inhabit the world as it is, as it is also for students on the programme. As should be evident, theory and scholarship is greatly valued but only insomuch as it has demonstrable value to learners.

To work as a WBIS tutor requires an understanding of university processes, learning levels, learning outcomes and credit systems. Expertise is also required in the creation of award titles and curriculums. Most academics will never design a programme let alone negotiate one with students or organisations. For WBIS tutors it is an everyday experience. The ability to identify and process claims for past learning and the facilitation of trans-disciplinary workplace projects are also essential attributes. The focus on learning also requires the ability to offer formative assessment for all assignments. Tutors must also be able to create e-learning resources and deliver workplace workshops. Like every effective team WBIS staff do not share the same skill set and underpinning knowledge capability (Belbin 1981). Given the distinctiveness of WBIS it 
takes time for new tutors to develop so there is a clear process of participation from peripheral to legitimate within a clearly defined community of practice (Talbot and Leonard 2009).

\section{Conclusion}

The reflections in this paper have been prompted by specific events. The twenty years of policy failure for lifelong learning in the UK outlined at the onset has coincided with the twenty years in which WBIS has flourished. Within the field of flexible WBL, the breaking up of the Institute for Work Based Learning at Middlesex in 2018, long the internationally recognised 'brand leader' in flexible WBL for adults, is in our world, a seismic event. But it is not the only centre to be closed- there are many other examples. The demise of Middlesex and others might in part be attributable to circumstances which are UK-specific but we believe there are significant challenges associated with the incorporation of any radical model of flexible, experiential learning within a conventional university setting and this is a universal issue. The factors which have made WBIS a success require a degree of luck, such as the same supportive Vice Chancellor for twenty years and skill sets not usually found in academics. Few academics wish to engage in regular marketing activities or are willing to engage in detailed analysis of funding matters, yet these have been essential for the progress of WBIS. Some lessons are evident from examples elsewhere, the prime example being the blindingly obvious: programmes which do not recruit students and cover their costs are never likely to last very long (Conole 2004; Garrett 2004; Perry 1976). As in all spheres of life, pragmatism is essential for utopianism to succeed (Levitas 2015). There are other examples of flourishing WBL centres and it would be useful to have accounts of their experience. But we should wonder what it takes to create the kind of sustainable flexible provision envisaged by policy makers rather more seriously in terms of their institutional requirements. The alternative is as Robinson (2007) argued, new missions for higher education requires new institutions. 
Footnotes

1 "A shell framework can be defined as a form of whole programme learning contract designed specifically to meet the requirements of adults in the workplace. They are validated programmes created by an accredited educational body which enables learners, either individually or in cohorts to negotiate their curriculum and in some cases award title, relevant to their professional practice. In contrast to a traditional validated program of study, a shell framework does not begin with the assumption that the objective of learning is instruction in a pre-determined subject. Instead it regards the subject of study a matter for negotiation between the learner and the educational body so that the learner is able to devise a curriculum and method which is relevant to their specific requirements. The purpose of study is to help them obtain a relevant qualification, receive recognition for their existing learning and develop personally and professionally. Shell frameworks can be for full or short awards either transdisciplinary or within a subject discipline(s). They are in many ways the polar opposite of the compulsory core curriculum for all." (Talbot 2017, pp. 1-2).

${ }^{2}$ The Learning from Experience Trust was a UK version of the US Council for Adult and Experiential Learning (CAEL) established in the 1970s to spread practices in relation to experiential learning in higher education. The Trust is currently non-operational: http://www.learningexperience.org.uk/ 


\section{References}

Alimo-Metcalfe, B. \& Alban-Metcalfe, J. (2005), “Leadership: Time for a new direction?”, Leadership, Vol. 1, No. 1, pp. 51-71.

Amenc, N. \& Le Sourd, V. (2003), Portfolio theory and performance analysis. Hoboken NJ: Wiley. Anonymous (2002), "Work-based learning standards low", Education \& Training, Vol. 44, No.7, pp. 332-340.

Aube, C. \& Rousseau, V. (2005), "Team goal commitment and team effectiveness: The role of task interdependence and supportive behaviors", Group Dynamics: Theory, Research, and Practice, Vol. 9, No. 3, pp. 189-204.

Barnett R (2014), Conditions of Flexibility: Securing a more responsive Higher Education system, The Higher Education Academy (HEA), York, United Kingdom.

Basit, T., Eardley, A., Borup, R., Shah, H., Slack, K. \& Hughes, A. (2015), “Higher education institutions and work-based learning in the UK: Employer engagement within a tripartite relationship". Higher Education, Vol. 70, pp. 1003-1015.

Beck, U. \& Beck-Gernshein, E. (2002), Individualization: Institutionalised individualization and its social and its social and political consequences, Sage, London, United Kingdom.

Belbin, R. (1981), Management teams: Why they succeed or fail, Butterworth Heinemann, Oxford, United Kingdom. 
Bennis, W. \& Goldsmith, J. (2010), Learning to lead: A workbook on becoming a leader. Basic Books, New York, NY.

Billett, S. (2001), Learning in the workplace: Strategies for effective practice, Allen \& Unwin, Sydney, Australia.

Bligh, D. (2000), What's the use of lectures?, Jossey Bass, San Francisco, CA.

Bloom, B., Hasting, S. \& Madaus, G. (1971), Handbook of formative and summative evaluation of student learning, McGraw-Hill, New York NY.

Boud, D. \& Solomon, N. (2001), Work-based learning: A new higher education?, Society for Research into Higher Education (SRHEA) and the Open University Press, Buckingham, United Kingdom.

Brookfield, S. (1985), Self-directed learning; from theory to practice: New directions for continuing education, Jossey Bass, San Francisco, CA.

Burns, T. \& Stalker, G. M. (1961), The management of innovation, Tavistock, London, United Kingdom. 
Callendar, C. \& Thompson, J. (2018), The lost part timers: The decline of part time undergraduate education in England, The Sutton Trust, London, United Kingdom. Retrieved from https://www.suttontrust.com/wp-content/uploads/2018/03/The-Lost-Part-TimersFinal.pdf

Carr. W, \& Kemmis, S. (1986), Becoming critical: Education, knowledge and action research, Routledge Falmer, London, United Kingdom.

Collini, S. (2012), What are universities for?, Penguin Books, London, United Kingdom.

Conole, G. (2004), "The Empire Strikes Back- organisational culture as a facilitator/inhibitor", Paper presented to the JISC Infonet conference, Published in Ferrell, G. (Ed.), When worlds collide: Changing cultures in twenty first century education, University of Northumbria, United Kingdom, pp. 27-34.

Costley, C. \& Pizzolato, N. (2017), "Transdisciplinary qualities in practice doctorates", Studies in Continuing Education, Vol. 40, No. 1, pp. 30-45.

Costley C \& Nottingham P (2018), "Revisiting search and review for work-based projects", Innovations in Education and Teaching International, Vol. 55, No.5, pp. 511-520. 
Davies, D. (2011), After scandal, what happens now to university of Wales? London, BBC News website 27 October. Retrieved from www.bbc.co.uk/news/uk-wales-15463655

Department for Education and Employment (1998), The Learning age: A renaissance for a new Britain. Cmd 3790, HMSO, London, United Kingdom. Retrieved from http://dera.ioe.ac.uk/15191/6/9780101379021 Redacted.pdf

Department for Education and Skills (2003), The future of higher education, Cmnd 5735, HMSO, Norwich, United Kingdom.

Deming Edwards W. (1994), The new economics for government, industry education, Center for Advanced Educational Services, Massachusetts Institute for Technology, Cambridge, Mass.

Dewey, J. (1916), Democracy and education: An introduction to the philosophy of education. Free Press, New York, NY.

Dreyfus, S. \& Dreyfus, H. (1980), A five-stage model of the mental activities involved in directed skill acquisition, Storming Media, Washington, DC. Retrieved from http://www.dtic.mil/dtic/tr/fulltext/u2/a084551.pdf 
Ehlers, U. \& Kellermann, S. (2019), Future skills: The future of learning and higher education. Results of the International Future Skills Delphi Survey, Baden Wurttemberg-Cooperative State University, Karlsruhe:DE.

(PDF) Future Skills - The Future of Learning and Higher education. Results of the International Future Skills Delphi Survey. Available from:

https://www.researchgate.net/publication/332028491_Future_Skills_-

_The_Future_of_Learning_and_Higher_education_Results_of_the_International_Future_Skills_ Delphi_Survey [accessed Apr 05 2019].

Eraut, M. (1994), Developing professional knowledge and competence, Falmer Press, London, United Kingdom.

Evans, N. (2000), "The evolution of AP(E)L in England", in Evans, N. (Ed.), Experiential learning around the world: Employability and the global economy, Jessica Kingsley Publishers, London, United Kingdom, pp. 49-82.

Field, J. (2018), "The Learning Age Keynote: Too many bright ideas to make a difference? Paper presented to The learning age - 20 years on: Whatever happened to our vision of a learning society?, 16 February, University of Wolverhampton, Wolverhampton, United Kingdom.

Flyvbjerg, B. (2001), Making social science matter: Why social enquiry fails and how it can succeed again, Cambridge University Press, Cambridge, United Kingdom. 
Garnett, J. (2007), “Challenging the structure capital of the university to support work based learning", in Young, D. \& Garnett, J. (Eds.), Work based learning futures: Proceedings from the Work based learning futures conference Bolton, United Kingdom, University Vocational Awards Council (UVAC), Bolton, United Kingdom, pp. 21-27.

Garrett, R. (2004), "The real story behind the failure of UK eUniversity", Educause Quarterly, No.4, pp. 4-6. Retrieved from http://suewatling.blogs.lincoln.ac.uk/files/2012/12/The-realstory-behind-thefailure-of-the-UK-e-university-by-Garrett.pdf

Giddens. A. (1991), Modernity and self identity: Self and society in the Late Modern Age, Polity Press, Cambridge, United Kingdom.

Gibbons, M., Limoges, C., Notwotny, H., Schwartzman, S., Scott, P. \& Trow, M. (1994), The new production of knowledge: The dynamics of science and research in contemporary societies, Sage, London, United Kingdom.

Gustavs, J. \& Clegg, S. (2005), "Working the knowledge game? Universities and corporate organisations in partnerships", Management Learning, Vol. 36, No. 1, pp. 9-30. 
Hillman, N., Dickinson., J, Rubbra, A. \& Klamann, Z. (2018), Where do student fees really go? Following the pound, Higher Education Policy Institute (HEPI), Oxford, United Kingdom.

Retrieved from https://www.hepi.ac.uk/wp-content/uploads/2018/11/Following-the-pound.pdf

King, A. (1993), "From sage on the stage to guide on the side", College Teaching, Vol. 41, No 1, pp. 30-35.

Kluger, A. \& DeNisi, A. (1996), "The effects of feedback interventions on performance: A historical review, a meta-analysis, and a preliminary feedback intervention theory", Psychological Bulletin, Vol. 119, No. 2, pp. 254-284.

Knowles, M. (1986), Using learning contracts, Jossey Bass, San Francisco, CA.

Knowles, M., Holton, E. \& Swanson, R. (1998), The adult learner: The definitive classic in adult education and human resource development, (5th Ed.), Butterworth-Heinemann, Woburn Mass.

Kolb, D. (1984), Experiential learning: Experience as the source of learning and development, Prentice-Hall, Englewood Cliffs, NJ.

Lambert, R. (2003), The Lambert review of business-industry collaboration: Final report, HM Treasury, London, United Kingdom. 
Lave, J. \& Wenger, E. (1991), Situated learning: Legitimate peripheral participation, Cambridge University Press, Cambridge, United Kingdom.

Leitch, S. (2006), Prosperity for all in the global economy- World class skills: Final report, HM Treasury, London, United Kingdom. Retrieved from https://www.gov.uk/government/uploads/system/uploads/attachment data/file/243599/0118 404865.pdf

Lester, S. (2015), “A vocational qualification system fit for adults? Revisiting some ideas from the University for Industry", Higher Education, Skills and Work-Based Learning, Vol. 5, No. 2, pp.102116.

Lester, S. \& Costley, C. (2010), “Work-based learning at higher education level: Value, practice and critique", Studies in Higher Education, Vol. 35, No. 5, pp. 561-575.

Levitas, R. (2015), “Pragmatism, Utopia and Anti-Utopia”, Critical Horizons, Vol. 9, No. 1, pp. 4259.

Lewin, K. (1951). Field theory in social science: Selected theoretical papers, (Ed. Cartwright, D.), Harper \& Row, New York, NY. 
Marsick, V. \& Watkins, K. (Eds.) (1990), Informal learning and incidental learning in the workplace, Routledge, London, United Kingdom.

National Audit Office (2002), Individual Learning Accounts, Report by the Comptroller and Auditor General, HC 1235, Session 2001-2002, House of Commons, London, United Kingdom. Retrieved from https://www.nao.org.uk/wp-content/uploads/2002/10/01021235.pdf

Nicolescu, B. (2002), Manifesto of transdisciplinarity (Trans. Voss, K.), State University of New York Press, Albany, NY.

Nixon, I., Smith, K., Stafford, R. \& Camm, S. (2006), Work based learning: Illuminating the higher education landscape: Final report, Higher Education Academy (HEA), York, United Kingdom, Retrieved from:

https://www.heacademy.ac.uk/system/files/wbl illuminating.pdf

Nonaka, I. \& Takeuchi, H. (1995), The knowledge creating company: How Japanese companies create the dynamics of innovation, Oxford University Press, New York, NY.

O’Reilly, D. (1989), “Negotiating in an institutional context”, in Stephenson, J. \& Laycock, M. (Eds.), Using learning contracts in higher education, Routledge, London, United Kingdom, pp. 4654. 
Organisation for Economic Cooperation and Development (OECD) (2017), Education at a glance 2017: OECD indicators, Author, Paris, France. Retrieved from

http://www.keepeek.com/Digital-Asset-Management/oecd/education/education-at-a-glance2017 eag-2017-en\#.Wn2Dg6hl IU\#page1

Perry, W. (1976), Open University: A personal account by the first Vice Chancellor, Open University Press, Milton Keynes, United Kingdom.

Piper, J. \& Wilson, E. (1989), "Negotiating complete programmes of study”, in Stephenson, J. \& Laycock, M. (Eds.). Using learning contracts in higher education, Routledge, London, United Kingdom, pp. 40-44.

Polanyi, M. (1983), The tacit dimension, Peter Smith, Gloucester, Mass.

Portwood, D. \& Garnett, J. (2000), "The construction and validation of an institutional Work Based Learning programme", in Portwood, D. \& Costley, C. (Eds.), Work Based Learning and the University: New perspectives and practices, SEDA Paper 109, Staff and Educational Development Association, Birmingham, United Kingdom, pp. 45-50. Retrieved from

https://eprints.mdx.ac.uk/2693/1/SEDA\%20Paper\%20Chapter\%20Four\%20Portwood Garnett\% 20Split\%209.pdf.

Powell, A. (2017), Apprenticeships policy in England, House of Commons Library Briefing Paper CBP 03052, House of Commons, London, United Kingdom. Retrieved from file:///Y:/SN03052.pdf 
Prysor, D. \& Henley, A. (2018), “Boundary spanning in higher education leadership: Identifying boundaries and practices in a British university", Studies in Higher Education, Vol. 43, No. 12, pp. 2210-2225, DOI: 10.1080/03075079.2017.1318364.

Quality Assurance Agency (QAA) (2010), Institutional audit: University of Chester, Author, Gloucester, United Kingdom. Retrieved from http://www.qaa.ac.uk/en/ReviewsAndReports/Documents/University\%20of\%20Chester/Univer sity-of-Chester-IA-10.pdf

Raelin, R. (1999), Work based learning: The new frontier of management development, Financial Times and Prentice Hall, London, United Kingdom.

Redecker, C. \& Punie, Y. (2013), The future of learning 2025: Developing a vision for change, Future Learning, No. 1, pp. 3-1, DOI: 10.7564/13-FULE12. Retrieved from https://www.researchgate.net/publication/260863799 The Future of Learning 2025 Develo ping a vision for change

Reeve, F. \& Gallacher, J. (2005), “Employer-university 'partnerships': A key problem for workbased learning programmes?", Journal of Education and Work, Vol. 18, No. 2, pp. 219-233.

Robinson, E. (2007), "1966 and all that: A revolution in higher education that is yet complete", Higher Education Review, Vol. 39, No. 3, pp. 45-58. 
Rogers, C. \& Freiberg, H. (1994), Freedom to learn (3rd. Ed.), Macmillan, New York NY.

Rowe. L., Moss, D., Moore, N. \& Perrin, D. (2017), "The challenges of managing degree apprentices in the workplace: A manager's perspective", Journal of Work-Applied Management, Vol. 9, No. 2, pp. 185-199.

Scriven, M. (1967), “The methodology of evaluation”, in Stake R. (Ed.), Curriculum evaluation, Rand McNally, American Educational Research Association, Chicago, III, pp. 59-85.

Shattock, M. (2010), Managing successful universities, McGraw Hill and the Open University, Maidenhead, United Kingdom.

Smith E (2001), "The role of tacit and explicit knowledge in the workplace", Journal of Knowledge Management, Vol. 5, No. 4, pp. 311-321.

Sutherland, J. (1998), Workplace learning for the twenty first century: Report of the Workplace Learning Task Group, Unison, London, United Kingdom.

Talbot, J. \& Leonard, D. (2009), Developing new work based learning pathways for housing practitioners whilst participating peripherally and legitimately: The situated learning of work based learning tutors, in Young, D. \& Garnett, J. (Eds.), Proceedings from the Work based 
learning futures III conference, University Vocational Awards Council (UVAC), Bolton, United Kingdom, pp. 6-20.

Talbot J, Perrin, D. \& Meakin, D. (2014), “Risk management and cultural virtue in HE co-delivery arrangements", Quality Assurance in Education, Vol. 22, No. 2, pp. 109-124.

Talbot, J. (2017), "Curriculum design for the post-industrial society: The facilitation of individually negotiated higher education in work based learning shell frameworks in the United Kingdom" in Nata, R. (Ed.) Progress in Education, 44, Nova Publications, New York, pp. 127-161.

Tuckett, A. (2017), "The rise and fall of life-wide learning for adults in England", International Journal of Lifelong Education, Vol. 36, nos. 1-2, pp. 230-249, DOI:

10.1080/02601370.2017.1274546.

Unit for the Development of Adult Continuing Education (UDACE) (1992). Learning outcomes in higher education, Further Education Development Agency, London, United Kingdom.

Universities UK (UUK) (2017), Patterns and trends in UK Higher Education 2017, Author, London, United Kingdom. Retrieved from http://www.universitiesuk.ac.uk/facts-and-stats/data-andanalysis/Documents/patterns-and-trends-2017.pdf

Vygotsky, L. (1978), Mind in society: The development of higher psychological processes (Cole, M. Trans.), Harvard University Press, Cambridge, MA. 
Wall, T. (2010), “University models of Work based learning validation”, in Roodhouse, S. \& Mumford, J. (Eds.), Understanding Work Based Learning, Gower, Aldershot, United Kingdom, pp. 41-54.

Wertsch, J. (1985), Vygotsky and the social formation of mind, Harvard University Press, Cambridge Mass.

Wiggins, G. (1998), Educative assessment, Jossey Bass, San Francisco, CA. 